\title{
A Survey of Negative Ions in Mass Spectra of Polyatomic Molecules
}

\author{
Robert M. Reese, Vernon H. Dibeler, and Fred L. Mohler
}

\begin{abstract}
A survey was made of negative-ion production in 27 different molecules covering a wide variety of chemical compounds. In nine compounds no ions were found. For the other compounds rough measurements of the appearance potentials and relative abundance of the ions are reported. About 60 different ionization processes are observed in 18 compounds. Formation of ions by dissociative resonance attachment is the most common process, but there are several cases of ion pair formation and of attachment without dissociation. Perchlorylfluoride gives by far the greatest abundance and variety of ions.
\end{abstract}

\section{Introduction}

Experimental data on mass spectra of negative ions $[1,2,3,4]^{1}$ are fragmentary and incomplete as compared with the extensive volume of research on positive ions. There are three different mechanisms by which negative ions can be formed by electron collision.

1. Ion pair formation $\mathrm{XY}+\mathrm{e} \rightarrow \mathrm{X}^{+}+\mathrm{Y}^{-}+\mathrm{e}$.

2. Resonance attachment $\mathrm{XY}+\mathrm{e} \rightarrow \mathrm{XY}^{-}$.

3. Resonance attachment with dissociation $\mathrm{XY}+\mathrm{e}$ $\rightarrow \mathrm{X}+\mathrm{Y}^{-}$.

In ion-pair formation the probability of ion formation increases with voltage above the ionization threshold in a manner similar to that of simple positive ion formation. In the two resonance attachment processes, ion formation occurs over a narrow range of voltage [5] at voltages ranging from 0 up to $10 \mathrm{v}$ or more. Thus a survey of negative-ion formation in a compound requires repeated sweeps of the mass spectrum at small voltage intervals from zero up.

Preliminary to a more detailed study of bonddissociation energies and electron affinities of halogenated molecules, a survey has been made of negative-ion production for a wide variety of compounds, and the results are reported in this paper.

\section{Experimental Details}

Most of the mass spectra were obtained with a $180^{\circ}$ Consolidated mass spectrometer of 5-in. radius of curvature with its circuits modified for appearance potential measurements [3]. Reversal of fields to collect either positive or negative ions was accomplished without difficulty, except that the d-c amplifier showed marked alinearity for negative-ion currents greater than $3 \times 10^{-12}$ amp. In a recent experiment with $\mathrm{CCl}_{4}$, a new $60^{\circ}$ sector field instrument was used, and, probably because of improved means of focusing, some details were observed that were unmeasurable with the $180^{\circ}$ instrument. In an experiment with $\mathrm{C}_{2} \mathrm{~F}_{6}$ a tungsten filament coated

1 Figures in brackets indicate the literature references at the end of this paper. with lanthanum boride was substituted for the pure tungsten filament that is used routinely as an electron source. This resulted in an ion source temperature of about $150^{\circ} \mathrm{C}$ instead of $250^{\circ} \mathrm{C}$.

Negative ions formed by attachment processes were first detected by repeated sweeping of portions of the spectrum while varying the electron energy from 0 to $20 \mathrm{v}$, and negative ions formed by ion-pair processes were detected at $100 \mathrm{v}$. Data for ionization-efficiency curves were then obtained by varying the electron energy in $0.2-\mathrm{v}$ steps from 0 to $20 \mathrm{v}$ and in larger increments up to $100 \mathrm{v}$. Curves were plotted on a linear scale.

The relative efficiency for collecting negative ions produced by resonance capture as compared with positive ions depends critically on the operating conditions. The collecting efficiency of the $180^{\circ}$ mass spectrometer has been estimated by a method used by Marriott and Craggs [2]. Lozier [6] made measurements of the relative abundance of positive and negative ions from oxygen in a nearly field-free space and found the ratio $\mathrm{O}^{-} / \mathrm{O}^{+}=0.04$ at $35 \mathrm{v}$. This instrument gave a ratio of about 0.0125 , and the collecting efficiency is taken to be 31 percent.

This paper reports observed appearance potentials without any correction for effects of contact potentials and the electric field across the ionization chamber. A comparison with published results indicates that the correction would be less than $1 \mathrm{v}$.

\section{Results}

Table 1 summarizes the data obtained for 18 compounds. Nine others - diborane, $\mathrm{B}_{2} \mathrm{H}_{6}$; decaborane, $\mathrm{B}_{10} \mathrm{H}_{14}$; triethylborane $\mathrm{B}\left(\mathrm{C}_{2} \mathrm{H}_{5}\right)_{3}$; dimethylaminodiborane, $\left(\mathrm{CH}_{3}\right)_{2} \mathrm{NB}_{2} \mathrm{H}_{5}$; ethane; 1-pentene; benzene; methyfluoroform, $\mathrm{CH}_{3} \mathrm{CF}_{3}$; and 1,1-difluoroethylene, $\mathrm{CH}_{2}=\mathrm{CF}_{2}$; were also investigated. No negative ions were observed for these compounds over an electron energy range from 0 to $90 \mathrm{v}$.

In table 1, column 1 gives the compound. Column 2 lists the ions observed in each compound. Column 3 gives the appearance potentials of the ions and, after each entry, the letters $(\mathrm{A})$ and $(\mathrm{P})$ designate 
TABLE 1. Negative ions from polyatomic molecules

\begin{tabular}{|c|c|c|c|c|}
\hline Compound & Ion & $\begin{array}{l}\text { Appearance } \\
\text { potential } 1\end{array}$ & $\begin{array}{l}\text { Per- } \\
\text { centage } \\
\text { abun- } \\
\text { dance } 2\end{array}$ & Remarks \\
\hline $\mathrm{CO}$ & $\mathrm{O}^{-}$ & $\begin{array}{l}e v \\
10.0(\mathrm{~A}) \\
21.5(\mathrm{P})\end{array}$ & $\begin{array}{l}1.7 \\
0.5\end{array}$ & $\begin{array}{l}9.6 \mathrm{ev} \mathrm{[5]} \\
20.9 \mathrm{ev}[5] .\end{array}$ \\
\hline $\mathrm{O}_{2}$ & $\mathrm{O}^{-}$ & $\begin{array}{r}5.4(\mathrm{~A}) \\
17.8(\mathrm{P})\end{array}$ & $\begin{array}{l}.5 \\
.4\end{array}$ & $\begin{array}{l}4.7 \mathrm{ev}[8] . \\
17.1 \mathrm{ev} \text { and } 20.2 \mathrm{ev}[8] .\end{array}$ \\
\hline $\mathrm{HCl}$ & $\mathrm{Cl}^{-}$ & $0.4(\mathrm{~A})$ & $-\cdots$ & \\
\hline $\mathrm{CCl}_{4}$ & $\begin{array}{c}\mathrm{Cl}^{-} \\
\mathrm{Cl}_{2-}^{-} \\
\mathrm{CCl}_{3}-\end{array}$ & $\begin{array}{l}0 \quad(\mathrm{~A}) \\
5.6(\mathrm{~A}) \\
13(\mathrm{P}) \\
0.8(\mathrm{~A}) \\
1.4(\mathrm{~A})\end{array}$ & $\begin{array}{r}13.5 \\
3.7 \\
0.5 \\
.3 \\
.03\end{array}$ & $\begin{array}{l}180^{\circ} \text { mass spectrometer. } \\
60^{\circ} \text { mass spectrometer. } \\
60^{\circ} \text { mass spectrometer. } \\
180^{\circ} \text { mass spectrometer. } \\
180^{\circ} \text { mass spectrometer. }\end{array}$ \\
\hline $\mathrm{B}_{5} \mathrm{H}_{9}$ & $\begin{array}{l}\mathrm{B}_{5} \mathrm{H}_{6-} \\
\mathrm{B}_{5} \mathrm{H}_{7-} \\
\mathrm{B}_{5} \mathrm{H}_{8-} \\
\mathrm{B}_{5} \mathrm{H}_{9-}\end{array}$ & $\begin{array}{l}3.0(\mathrm{~A}) \\
2.0(\mathrm{~A}) \\
1.4(\mathrm{~A}) \\
1.0(\mathrm{~A})\end{array}$ & $\begin{array}{r}(20) \\
(57) \\
(100) \\
(80)\end{array}$ & $\begin{array}{l}\text { Not compared with } \\
\text { positive ion abun- } \\
\text { dance. }\end{array}$ \\
\hline $\mathrm{CH}_{2} \mathrm{~F}_{2}$ & $\mathrm{~F}^{-}$ & 19. $2(\mathrm{P})$ & 0.3 & \\
\hline $\mathrm{CHF}_{2} \mathrm{Br}$ & $\mathrm{Br}^{-}$ & $0 \quad(\mathrm{~A})$ & $-\cdots$ & $-\cdots$ \\
\hline $\mathrm{ClO}_{3} \mathrm{~F}$ & $\left\{\begin{array}{c}\mathrm{F}^{-} \\
\mathrm{O}^{-} \\
\mathrm{O}_{2}^{-} \\
\mathrm{Cl}^{-} \\
\mathrm{ClO}^{-} \\
\\
\mathrm{ClO}_{2}^{-} \\
\mathrm{ClO}_{3}^{-} \\
\mathrm{ClO}_{2} \mathrm{~F}^{-}\end{array}\right.$ & $\begin{array}{l}0 \text { (A) } \\
4.3 \text { (A) } \\
3.7 \text { (A) } \\
7.4 \text { (A) } \\
3.2 \text { (A) } \\
0 \text { (A) } \\
4.8 \text { (A) } \\
2.4 \text { (A) } \\
4.6 \text { (A) } \\
8.5 \text { (A) } \\
0 \text { (A) } \\
4.3 \text { (A) } \\
0 \text { (A) } \\
0 \text { (A) }\end{array}$ & $\begin{array}{c}300 \\
30 \\
2 \\
0.4 \\
.3 \\
24 \\
0.2 \\
.2 \\
.4 \\
.2 \\
10 \\
3 \\
400 \\
15\end{array}$ & $\begin{array}{c}-1 \\
-\end{array}$ \\
\hline $\mathrm{CF}_{3} \mathrm{H}$ & $\mathrm{F}^{-}$ & $26.1 \pm 1(\mathrm{P})$ & 0.03 & $\ldots$ \\
\hline $\mathrm{C}_{3} \mathrm{~F}_{7} \mathrm{Br}$ & $\begin{array}{l}\mathrm{F}^{-} \\
\mathrm{Br}^{-} \\
\mathrm{FBr}^{-}\end{array}$ & $\begin{array}{l}2.6(\mathrm{~A}) \\
8.5(\mathrm{~A}) \\
00(\mathrm{~A}) \\
3.4(\mathrm{~A}) \\
3.2(\mathrm{~A})\end{array}$ & $\begin{array}{r}.8 \\
.3 \\
43.5 \\
3 \\
0.1\end{array}$ & $\begin{array}{c}-4-1 \\
-10\end{array}$ \\
\hline $\mathrm{CF}_{3} \mathrm{C}_{8} \mathrm{H}_{5}$ & $\mathrm{~F}^{-}$ & - & --. & Very low abundance. \\
\hline $\mathrm{C}_{2} \mathrm{~F}_{6}$ & $\underset{\mathrm{CF}}{\mathrm{CF}_{3}^{-}}$ & $\begin{array}{l}4.3(\mathrm{~A}) \\
4.6(\mathrm{~A})\end{array}$ & $\begin{array}{l}.3 \\
.4\end{array}$ & $\mathrm{LaB}_{6}$ on filament. \\
\hline $\mathrm{C}_{3} \mathrm{~F}_{8}$ & $\mathrm{CF}_{3}-$ & $3.5 \pm 0.5(\mathrm{~A})$ & $\cdots$ & Very low abundance. \\
\hline eyclo $\mathrm{C}_{4} \mathrm{~F}_{8}$ & $\begin{array}{c}\mathrm{F}^{-} \\
\mathrm{CF}_{3}^{-}\end{array}$ & $\begin{array}{r}3.9(\mathrm{~A}) \\
7.3(\mathrm{~A}) \\
11.0(\mathrm{~A}) \\
4.8(\mathrm{~A})\end{array}$ & $\begin{array}{r}(100) \\
(35) \\
(19) \\
(4)\end{array}$ & $\begin{array}{l}\text { Not compared with } \\
\text { positive ions. }\end{array}$ \\
\hline$n-\mathrm{C}_{4} \mathrm{~F}_{10}$ & $\begin{array}{l}\mathrm{F}^{-} \\
\mathrm{CF}_{3}^{-} \\
\mathrm{C}_{2} \mathrm{~F}_{5}^{-} \\
\mathrm{C}_{3} \mathrm{~F}_{7^{-}}^{-} \\
\mathrm{C}_{4} \mathrm{~F}_{9^{-}}\end{array}$ & $\begin{array}{l}1.2(\mathrm{~A}) \\
3.3(\mathrm{~A}) \\
2.8(\mathrm{~A}) \\
2.8(\mathrm{~A}) \\
2.1(\mathrm{~A}) \\
4.1(\mathrm{~A})\end{array}$ & $\begin{array}{l}3.5 \\
0.03 \\
.6 \\
.2 \\
.2 \\
.2\end{array}$ & $\begin{array}{l}-1 \\
-1\end{array}$ \\
\hline $\mathrm{CF}_{3} \mathrm{cyC}_{6} \mathrm{~F}_{11}$ & $\left\{\begin{array}{l}\mathrm{C}_{6} \mathrm{~F}_{8}^{-} \\
\mathrm{C}_{6} \mathrm{~F}_{11^{-}}\end{array}\right.$ & $\begin{array}{ll}0 & (\mathrm{~A}) \\
0 & (\mathrm{~A})\end{array}$ & $\begin{array}{r}(24) \\
(100)\end{array}$ & $\begin{array}{l}\text { Not compared with } \\
\text { positive ions. }\end{array}$ \\
\hline$n-\mathrm{C}_{7} \mathrm{~F}_{16}$ & $\left\{\begin{array}{c}\mathrm{F}^{-} \\
\mathrm{C}_{3} \mathrm{~F}_{7^{-}} \\
\mathrm{C}_{4} \mathrm{~F}_{9-}^{-} \\
\mathrm{C}_{5} \mathrm{~F}_{11^{-}} \\
\mathrm{C}_{7} \mathrm{~F}_{16^{-}}\end{array}\right.$ & $\begin{array}{ll}1.6 & (\mathrm{~A}) \\
& \\
8.5 & (\mathrm{~A}) \\
0 & (\mathrm{~A}) \\
0 & (\mathrm{~A}) \\
0 & (\mathrm{~A}) \\
0 & (\mathrm{~A})\end{array}$ & $\begin{array}{r}(100) \\
(22) \\
(100) \\
(99) \\
(32) \\
(99)\end{array}$ & $\begin{array}{l}\begin{array}{l}\text { Not compared with } \\
\text { positive ions. }\end{array} \\
\end{array}$ \\
\hline $\mathrm{C}_{6} \mathrm{~F}_{6}$ & $\begin{array}{c}\mathrm{F}^{-} \\
\mathrm{C}_{6} \mathrm{~F}_{5-}^{-} \\
\mathrm{C}_{6} \mathrm{~F}_{6-}^{-}\end{array}$ & $\begin{array}{l}3.9(\mathrm{~A}) \\
8.2(\mathrm{~A}) \\
4.5(\mathrm{~A}) \\
8.4(\mathrm{~A}) \\
0 .(\mathrm{A})\end{array}$ & $\begin{array}{l}0.7 \\
.5 \\
.2 \\
.04 \\
.1\end{array}$ & - \\
\hline
\end{tabular}

${ }_{1}^{1}$ The appearance potential is the uncorrected applied potential. In most cases this was measured with a precision of about $0.2 \mathrm{ev}$. Resonance attachment processes are denoted by $(\mathrm{A})$, ion-pair process by $(\mathrm{P})$.

${ }_{2}$ The abundance is expressed relative to the most abundant positive ion, except that numbers in parentheses are relative to the most abundant attachment process. resonance attachment processes and ion pair processes, respectively. Column 4 gives the relative abundance of the negative ions. For attachment processes the maximum of the resonance peak was compared with the most abundant positive ion at $70 \mathrm{v}$, using the correction factor described above for relative efficiency of collecting negative ions. In some cases the comparison with positive ion abundance was not made and numbers in paren theses give the relative intensity of the different resonance peaks. Under "Remarks" some published measurements of appearance potentials of ions in $\mathrm{CO}$ and $\mathrm{O}_{2}$ are included. These indicate that the uncorrected values of appearance potentials in column 3 are within less than $1 \mathrm{v}$ of the corrected values.

\section{Discussion}

Table 1 lists 61 different ionization processes found in the 18 compounds and most of these involve dissociative resonance capture. There are only five ion pair processes and these are all of low abundance. Resonance attachment without dissociation is observed only in $\mathrm{B}_{5} \mathrm{H}_{9}, n-\mathrm{C}_{7} \mathrm{~F}_{16}$, and $\mathrm{C}_{6} \mathrm{~F}_{6}$. In general, the relative abundance of negative ions is small compared with positive ions but the compound perchlorylfluoride, $\mathrm{ClO}_{3} \mathrm{~F}$, is a notable exception. In this compound there is a wide variety of ions formed by attachment and there are often several attachment potentials for each ion. The table includes data on seven perfluorohydrocarbons and these show wide variations in the negative ion spectra. In $\mathrm{C}_{3} \mathrm{~F}_{8}$ only one ion of very low abundance appears whereas in all the heavier fluorocarbons a variety of ions is found. It is of interest that in $n-\mathrm{C}_{7} \mathrm{~F}_{16}$ the molecule ion is large. In the positive ion spectrum the molecule ion is not observed.

Five compounds containing boron were studied but only in pentaborane, $\mathrm{B}_{5} \mathrm{H}_{9}$, were negative ions found and in this case four different ions were observed.

The following diatomic negative ions cannot be formed by simple dissociation; $\mathrm{Cl}_{2}{ }^{-}$from $\mathrm{CCl}_{4}, \mathrm{FBr}^{-}$ from $\mathrm{C}_{3} \mathrm{~F}_{7} \mathrm{Br}$ and $\mathrm{O}_{2}{ }^{-}$from $\mathrm{ClO}_{3} \mathrm{~F}$.

There are some published researches on negative ions of $\mathrm{HCl}$ and $\mathrm{CCl}_{4}$. Gutbier and Neuert [9] find appearance potentials for $\mathrm{Cl}^{-}$from $\mathrm{HCl}$ at $0.8 \pm 0.3$ $\mathrm{ev}, 4 \pm 1 \mathrm{ev}$ and $13.6 \pm 0.5 \mathrm{ev}$, the latter being an ion pair process. The ion pair process and the $4 \mathrm{v}$ resonance could not be found in this work although measurements were made with both the $180^{\circ}$ instrument and the $60^{\circ}$ instrument.

For $\mathrm{CCl}_{4}$ Baker and Tate [10] give appearance potentials of $\mathrm{Cl}^{-}$as $1.3 \pm 0.3,5.8 \pm 0.5$, and 12.4 $\pm 0.2 \mathrm{ev}$, which is consistent with data of table $1 \mathrm{but}$ they find $\mathrm{Cl}_{2}{ }^{-}$at $4.8 \pm 1$ and $17.0 \pm 0.5$ and small peaks of $\mathrm{C}^{-}$and $\mathrm{CCl}^{-}$. Craggs, McDowell, and Warren [11] find only one capture peak for $\mathrm{Cl}^{-}$near $6 \mathrm{ev}$, and the ion pair process. In this research, measurements with the $180^{\circ}$ instrument showed only the $0-\mathrm{v}$ appearance potential for $\mathrm{Cl}^{-}$. 
The discrepancies in experimental results reflect some of the inherent difficulties in research on negative ions. One recognized difficulty is that the relative intensity of sharp resonance peaks will depend on the energy spread of the electron beam and, if the sharp peak is at $0 \mathrm{v}$, the fraction of electrons of nearly $0 \mathrm{v}$ may be subject to extreme variations. Another difficulty is that negative ions frequently have high kinetic energy, so that the efficiency of collecting the ions is low and variable. For these reasons research on the relative abundance of negative ions is in a qualitative stage of development.

Only a preliminary survey of the negative ion spectra is given and further research on some of the compounds is now in progress. An apparatus is being assembled to study ion formation with a nearly monoenergetic electron beam using the technique of Fox et al, [12]. This method should materially reduce experimental uncertainties in appearance potential measurements and afford valuable information on bond energies and electron affinities.

\section{References}

[1] J. D. Craggs and C. A. MeDowell, Repts. Progr. in Phys. 18, 375 (1955).

[2] J. Marriott and J. D. Craggs, Applied mass spectrometry, p. 180, Inst. Petroleum (London, 1954).

[3] V. H. Dibeler and R. M. Reese, J. Research NBS 54, 127 (1955).

[4] V. H. Dibeler, R. M. Reese, and F. L. Mohler, J. Research NBS 5\%, 113 (1956) RP2700.

[5] W. M. Hickam and R. E. Fox, Phys. Rev. 98, 557 (1955).

[6] W. W. Lozier, Phys Rev 46, 268 (1934).

[7] H. D. Hagstrum, J. Chem. Phys. 23, 1178 (1955).

[8] R. Thorburn, Applied mass spectrometry, p. 185, Inst. Petroleum (London, 1954).

[9] H. Gutbier and H. Neuert, Z. Naturforsch. 9a, 335 (1954).

[10] R. F. Baker and J. T. Tate, Phys. Rev. 53, 683 (1938).

[11] J. D. Craggs, C. A. McDowell, and J. W. Warren, Trans. Far. Soc. 48, 1093 (1052).

[12] R. E. Fox, W. M. Hickam, D. J. Grove, and T. Kjeldaas, Jr., Rev. Sci. Inst. 26, 1101 (1955).

Washington, July 30, 1956. 